\title{
Pastoral suitability driven by future climate change along the Apennines
}

\author{
Camilla Dibari, ${ }^{1}$ Giovanni Argenti, ${ }^{1}$ Francesco Catolfi, ${ }^{1}$ Marco Moriondo, ${ }^{2}$ Nicolina Staglianò,, \\ Marco Bindi ${ }^{1}$ \\ ${ }^{1}$ Department of Agri-Food Production and Environmental Sciences, University of Florence; \\ ${ }^{2}$ Institute of Biometeorology, National Research Council, Florence, Italy
}

\begin{abstract}
This work aims at evaluating the impacts of climate change on pastoral resources located along the Apennines chain. To this end, random forest machine learning model was first calibrated for the present period and then applied to future conditions, as projected by HadCM3 general circulation model, in order to simulate possible spatial variation/shift of pastoral areas in two time slices (centred on 2050 and 2080) under A2 and B2 SRES scenarios. Pre-existent spatial database, namely Corine land cover map and WorldClim, were integrated and harmonised in a GIS environment in order to extract climate variables (mean seasonal precipitation, mean maximum temperature of the warmest month and minimum temperature of the coldest month) and response variables (presence/absence of pastures) to be used as model predictors. Random forest model resulted robust and coherent to simulate pastureland suitability under current climatology (classification accuracy error=19\%). Accordingly, results indicated that increases in temperatures coupled with decreases in precipitation, as simulated by HadCM3 in the future, would have impacts of great concern on potential pasture distribution. In the specific, an overall decline of pasturelands suitability is predicted by the middle of the century in both A2 $(-46 \%)$ and B2 $(-41 \%)$ along the entire chain. However, despite alarming reductions in pastures suitability along the northern ( $-69 \%$ and $-71 \%$ under A2 and B2 scenarios, respectively) and central Apennines ( $-90 \%$ under both scenarios) by the end of the century, expansions are predicted along the southern areas of the
\end{abstract}

Correspondence: Camilla Dibari, Department of Agri-Food Production and Environmental Sciences (DISPAA), University of Florence, P.le delle Cascine 18, 50144 Florence, Italy.

E-mail: camilla.dibari@unifi.it

Key words: Permanent pastures; Apennines; climate change; random forest; pastoral suitability.

Conference presentation: SIA XLIII Congress, Pisa, 2014.

Received for publication: 30 January 2015.

Revision received: 11 May 2015.

Accepted for publication: 11 May 2015.

(c) Copyright C. Dibari et al., 2015

Licensee PAGEPress, Italy

Italian Journal of Agronomy 2015; 10:659

doi:10.4081/ija.2015.659

This article is distributed under the terms of the Creative Commons Attribution Noncommercial License (by-nc 3.0) which permits any noncommercial use, distribution, and reproduction in any medium, provided the original author(s) and source are credited. chain ( $+96 \%$ and $+105 \%$ under A2 and B2 scenarios, respectively). This may be probably due to expansions in pastures dominated by xeric and thermophiles species, which will likely benefit from warmer and drier future conditions predicted in the southern zone of the chain by the HadCM3. Hence, the expected climate, coupled with an increasing abandonment of the traditional grazing practices, will likely threat grassland biodiversity as well as pastoral potential distribution currently dominating the Apennines chain.

\section{Introduction}

Evidence shows that in the last century the Mediterranean basin, acknowledged as very sensitive to climate variation (Lionello et al., 2006; IPCC, 2014), experienced relevant increases in temperature combined with noteworthy reductions in precipitation, and, according to future scenarios, this tendency is expected to even worsen in the next decades (Bravo et al., 2008; Giorgi and Lionello, 2008; Hertig et al., 2010; Lionello et al., 2014). This trend will likely impact many plant ecosystems, especially those located in mountain areas where climate is one of the major drivers of their distribution.

Recent findings on European mountain systems indicate that global warming is leading to thermofilisation processes with upwards shifts of the more thermophile herbaceous species and a consequent detriment of cold-tolerant high-altitude grassland communities (Gottfried et al., 2012). This trend was observed also on the mountainside belt of the Majella massif of the Apennines (Stanisci et al., 2005a, 2005b), where eastward exposures are expected to be encroached by thermophile species currently dominating the lower altitudes, whilst northward exposures, characterised by shorter frost-free periods, will likely show greater inertia toward invasive processes by thermophile species. Accordingly, potential plants shift to higher altitudes could be limited by low altitudinal gradients, by restrictions in available surface areas, by presence of rocks or by potential dispersal ability of species. Moreover, upwards shifts will likely be affected by changes in ecosystems composition and species competition, as cold-tolerant species, which generally require short growing season, will be likely exposed to a remarkable competition by species more suited to the altered climatic conditions (Kudernatsch et al., 2008; Cornelius et al., 2012). Thus, given the projected climate changes, high-altitude and endemic grassland ecosystems dominating the European mountains will likely and seriously face risks of extinction.

In Mediterranean regions, plant responses to climate change may be strongly driven by redistribution of water in time and space (Gasith and Vincent, 1999). Decreases and seasonal variability in precipitation projected in the next future will thus have severe consequences on vegetation productivity and composition, with effects in annual and inter-annual yield variability (Engler et al., 2011). In addition, increases in temperatures coupled with reduced precipitations will likely alter pastoral vegetation quality (i.e., pastoral value), favouring the expan- 
sion of grassland dominated by xeric species, which are characterised by a very low forage value (Targetti et al., 2010; Dibari et al., 2015).

Species distribution models are increasingly used in order to predict potentially suitable areas to ecosystems/habitats not covered by field surveys or where field data are incomplete or biased. Moreover, models have resulted robust and reliable to elaborate vegetation maps on a large scale-basis, as well as to assess the response of plant species to climate change (Gottfried et al., 1999; Latimer et al., 2006; Austin, 2007). Several statistical models have been applied to map climaterelated plant suitability (Guisan and Theurillat, 2000), and amongst them, machine learning models have proved good performances (Moriondo et al., 2008; Casalegno et al., 2011; Gaál et al., 2012; Moriondo et al., 2013a, 2013b). Moreover, several authors recommended random forest (RF) machine learning model for ecological and species distribution modelling applications (Prasad et al., 2006; Araùjo and Luoto, 2007) also at large scale extents (Prentice et al., 1992; Thuiller et al., 2008; Casalegno et al., 2011) because its characteristics of bootstrap-resampling, tree averaging and randomisation of predictors on big dataset (Attorre et al., 2011).

Building on these premises, in this study pasturelands response to the expected climate change was assessed along the entire Apennines chain. To this end, pre-existent spatial datasets were integrated in order to extract predictors and binary response variables to be used as inputs of RF model. Thus, potential pasturelands suitability was simulated and mapped under current climate and in two time slices (centred in 2050 and 2080) of two future climate scenarios (A2 and B2 SRES scenarios), in order to determine future trends of potential pastures distribution along the Apennines.

\section{Materials and methods}

\section{Study area}

From the border with the Alps (Cadibona Pass), the Apennines stretches over $1200 \mathrm{~km}$ from the northwest of Liguria region to the western extremity of Calabria region (Stretto di Messina). The study area extents about 6.5 million ha across the Apennine hilly range of Italy (approximately $38^{\circ}-45^{\circ}$ lat. $\mathrm{N}$ and $8^{\circ}-17^{\circ}$ long. E) at an altitude higher than $600 \mathrm{~m}$ above sea level. In this study, we refer to the northern Apennine those areas included in Liguria, Toscana and Emilia regions; to the central Apennine those ones included in the Abruzzo, Lazio, Marche, Molise and Umbria regions; to the southern Apennine those areas located within the Basilicata, Calabria, Campania and Puglia regions. The central Apennines show the highest peaks (Monte Corno, $2914 \mathrm{~m}$ asl belonging to the Gran Sasso massif of the Abruzzo region) along the chain. The climate can be classified as the mountain variant of the Mediterranean type with dry summers and rainy winters.

With more than $1.2 \mathrm{M}$ ha, the landscape of marginal areas of the Apennines, where other cultivations are often not profitable, is dominated by grasslands. Developed by a combination of local climate influence and centuries of livestock grazing, the mountain permanent pastures of the Apennines are species-rich ecosystems providing a range of goods and environmental services (e.g., forage, carbon stock, water retention, soil protection, attractions for local tourism, etc.) (Carlier et al., 2009). Moreover, pasturelands of the Apennines are characterised by several endemic species (some of them relictual) and different pastoral habitats, namely, lowland hay meadows, semi natural grasslands and scrubland facies on calcareous substrates, species-rich Nardus grasslands, on siliceous substrates, most of them currently under monitoring for proactive conservation purposes (Biondi et al., 2009).

\section{Input data and spatial data integration}

The current distribution of Apennine pasturelands was derived extracting the corresponding codes from Corine land cover (CLC) map database (2006), namely code 321 (Natural Grasslands), code 322 (Moors and Heatland) and code 324 (sclerophyllous vegetation). Altitude, current and future climate parameters (namely, monthly maximum and minimum temperature and precipitation) were extracted from the WorldClim database (Hijmans et al., 2005). WorldClim consists of a set of global topographic and climate georeferenced layers (grids) with approximately $1 \mathrm{x} 1 \mathrm{~km}$ spatial resolution. Current climate parameters of WorldClim, derived from the interpolation of meteorological observations spread all over the world, refer to $1950-2000$ baseline period. WorldClim future climatology derives instead from a statistical downscaling, performed by means of a correction factor, as simulated by the global circulation model (GCM) HadCM3 (Pope et al., 2000) applied to the baseline climatology over the climatic variation of mean temperature and precipitation for each grid cells. Moreover, WorldClim future climate data refer to A2 and B2 SRES scenarios, both referenced to two time slices (medium and long term period), 30 years long each, centred on 2050 and 2080, respectively.

With reference to the scientific literature (Attorre et al., 2011; Casalegno et al., 2011; Dibari, 2012), six climate variables were extracted and calculated to be used as model predictors. These comprise the monthly average of minimum temperature of the coldest month (January) (TMIN_Jan), the monthly average of maximum temperature of the warmest month (July) (TMAX_Jul), which are acknowledged as determinant to natural phytocoenoses sensitiveness (Todd et al., 2000; Benvenuti, 2009; Pasho et al., 2011). Moreover, the mean seasonal precipitation (Prec_DJF, Prec_MAM, Prec_JJA, Prec_SON, respectively referring to winter, spring, summer and autumn), were selected as model predictors since strongly influencing grasslands distribution (Heimann and Sept, 2000; Todd et al., 2000; Knapp et al., 2008).

By means of GIS procedures, polygons referred to natural pasturelands of CLC, in vector format in origin, were firstly reprojected and rasterised to the same coordinate reference system and spatial resolution of WorldClim (i.e., WGS84). Afterwards, the dataset was overlaid to the WorldClim climatic dataset in order to create a final comprehensive spatial grid cells dataset of $1 \times 1 \mathrm{~km}$ spatial resolution. This final dataset included, besides ID, longitude, and latitude, six predictors variables (TMAX_Jul, TMIN_Jan, Prec_DJF, Prec_MAM, Prec_JJA, Prec_SON) and one binary response variable (presence -1 and absence -0 of pasturelands) to be used as model inputs.

\section{Random forest}

The machine learning predictive model RF (Breiman, 2001) was employed for reproducing current pasturelands suitability and for assessing future climate impacts on the distribution of natural grasslands across the Apennine chain. RF consists of a combination of a large ensemble of decision tree classifiers widely used in ecological studies (Latimer et al., 2006; Evans and Cushman, 2009; Casalegno et al., 2011) especially for predicting climate changes effects on species distribution (Moriondo et al., 2008; Attorre et al., 2011; Moriondo et al., $2013 \mathrm{a}, 2013 \mathrm{~b})$. In RF, each classifier is generated using a bootstrap sample, which is randomly split into two subsets, one used for training (66\%) and one for internal testing (33\%, out-of-bag sample, 00B). The algorithm includes the computation of the $00 \mathrm{~B}$ error estimate, constituting an internal cross-validated accuracy estimates. RF algorithm also provides measures of variable importance; based on the computation of the mean decrease of classification accuracy, measure of how each variable contributes to the homogeneity of the nodes and leaves in the resulting random forest.

In this study, the RF model was first trained to simulate pasturelands 
distribution for the present period. The training dataset was organised in 15,818 one square kilometre cell grids to construct an input response/predictors table. Being the dataset highly unbalanced towards areas not covered by pastures (11,010 grid cells of pastures against 54,302 areas not covered by pastures), and considering that RF would tend to overestimate the majority class (Evans et al., 2011), the training dataset to feed RF was obtained using a five time reiterative one side sub-sampling, which included all the test cases where pastures occurred. Accordingly, the same number of test cases from those pixels not belonging to areas covered by pastures were also randomly sub sampled. The five random sub-sample RF models were comprehensively combined into a final model, which was in turn applied over the whole dataset. RF calibration was performed on randomly selected $80 \%$ of the dataset, while the $20 \%$ was used for validation. The accuracy of RF simulation was evaluated on the validation dataset by the 00B sample estimation. The probability scores outputs derived from RF application were converted into presence/absence prediction maps by computing the true skill statistic index (TSS) (Allouche et al., 2006) that minimised the prediction error. With regards to present period, the results of $\mathrm{RF}$ calibration was homogeneous for all the five reiterative one side sub-sampling dataset, reflecting a low variability in 00B error which ranged from $28 \%$ to $30 \%$ amongst the five sampling datasets. Calibration results indicated that the best RF performances were obtained with a threshold maximising TSS error index higher than 0.5 (TSS=0.99). Once calibrated, RF model was applied on the validation subset in order to estimate the classification accuracy error (CAE) of the classification process. Afterwards, RF was applied to the entire spatial datasets to reproduce current pasturelands suitability and to predict potential expansion/reduction and/or altitudinal shifts in two future time slices (centred on 2050 and 2080) under A2 and B2 SRES climatic scenarios as simulated by the HadCM3 GCM model. Finally, to quantify model response to climatic predictors variation, a sensitivity analysis was performed (data not shown). Accordingly, TMAX_Jul, TMIN_Jan were increased by $+1^{\circ} \mathrm{C},+3^{\circ} \mathrm{C}$ and $+5^{\circ} \mathrm{C}$, whilst seasonal rainfall parameters were varied by $-10 \%$ and $-30 \%$, and $+10 \%$ with respect to the current values.

\section{Results}

\section{Pastureland characterisation}

According to CLC map, natural pasturelands, located above $600 \mathrm{~m}$ of altitude, currently occupy $1,101,000$ ha across the Apennines, corresponding to $16.6 \%$ out of total of the study area (Table 1). Most of pas- toral resources are located across the central Apennines (57\% out of total), and, amongst them, the Abruzzo region accounts for the highest percentage (31\% out of total). In contrast, grasslands located across both northern and southern Apennines account in total for 43\% (16\% and $27 \%$, respectively). On average, the mean elevation of grasslands along the Apennines chain is $1043 \mathrm{~m}$; pasturelands located across the central Apennines show higher altitudes (1004 m of altitude) than across the northern and southern areas (865 and $905 \mathrm{~m}$, respectively).

\section{Current climate description}

The current climate of the study area, as described by WorldClim database for the present period, exhibits a large diversity of climatic characteristics across the three areas analysed (Table 1). In the specific, the spatial structure of the climatic parameters shows a NorthSouth pattern, with increasing temperatures along the chain. However, central and southern Apennines denote on average the highest TMAX_Jul values $\left(+24.5^{\circ} \mathrm{C}\right.$ and $+24.2^{\circ} \mathrm{C}$, respectively) with respect to the northern area $\left(+23^{\circ} \mathrm{C}\right)$. Similarly, TMIN_Jan shows an increasing trend ranging from $-1.6^{\circ} \mathrm{C}$ in the northern region of the chain to $+1.5^{\circ} \mathrm{C}$ in the southern.

Similarly, the cumulated annual precipitation of the study area shows a North-South decreasing pattern along the chain. In the specific, the northern Apennines accounts for the highest annual precipitation $(912 \mathrm{~mm})$, whilst the southern for the lowest $(759 \mathrm{~mm})$. On average, Autumn (Prec_SON) is the season denoting the highest precipitation along the three areas considered (Prec_SON=272 mm, on average), whilst, summer precipitation depicts the lowest values (Prec_JJA=142 mm, on average) with a remarkable North-South decreasing trend along the chain.

\section{Future climate description}

Future climate, as projected by HadCM3 under A2 and B2 emission scenarios, resulted in progressively warmer and drier conditions over the study area (Table 2). The progressively warmer conditions simulated by HadCM3 are mainly due to a remarkable increasing of TMAX_Jul, which is expected to increase on average by $+7.6^{\circ} \mathrm{C}$ and $+5.6^{\circ} \mathrm{C}$ in the long-term future time slice of A2 and B2 scenarios, respectively. The highest increases are mainly concentrated in the northern Apennines, whilst the lowest in the South. Though in a lower magnitude, also TMIN_Jan denotes an increasing trend (by $+2.8^{\circ} \mathrm{C}$ and $+1.8^{\circ} \mathrm{C}$ in the latest future under $\mathrm{A} 2$ and $\mathrm{B} 2$ scenarios, respectively), reflecting positive mean values already from half of the century. In the near (2050) and next (2080) future, an overall reduction in annual precipitation (Prec_Ann) is projected over the study area, more pronounced in the next future under the $\mathrm{A} 2$ scenario $(-18.1 \%)$ than in $\mathrm{B} 2(-5.9 \%)$, and

Table 1. Overall extension of current distribution of pastures (Pastureland) and other land use (Other land use) of the dataset. Altitude of pastures refers to the mean altitude of pasturelands. TMAX_Jul and TMIN_Jan are the average of the mean maximum temperature of the warmest month (July) and of the minimum temperature of the coldest month (January) along the study area, respectively. Prec_DJF, Prec_MAM, Prec_JJA and Prec_SON are the average rainfall during the winter, spring, summer and autumn season along the study area, respectively.

\begin{tabular}{|c|c|c|c|c|c|c|c|c|c|c|}
\hline Geographical & $\begin{array}{l}\text { Pastureland } \\
\text { (ha) }\end{array}$ & $\begin{array}{l}\text { Other } \\
\text { land use } \\
\text { (ha) }\end{array}$ & $\begin{array}{l}\text { Altitude of } \\
\text { pastures } \\
\text { (m) }\end{array}$ & $\begin{array}{c}\text { TMAX_Jul } \\
\left({ }^{\circ} \mathrm{C}\right)\end{array}$ & $\begin{array}{l}\text { TMIN } \\
\text { Jan } \\
\left({ }^{\circ} \mathrm{C}\right)\end{array}$ & $\begin{array}{l}\text { Prec } \\
\text { DJF } \\
(\mathrm{mm})\end{array}$ & $\begin{array}{l}\text { Prec } \\
\text { MAM } \\
(\mathrm{mm})\end{array}$ & $\begin{array}{c}\text { Prec_ } \\
\text { JJA } \\
(\mathrm{mm})\end{array}$ & $\begin{array}{l}\text { Prec } \\
\text { SON } \\
(\mathrm{mm})\end{array}$ & $\begin{array}{l}\text { Annual } \\
\text { precipitation } \\
\text { (mm) }\end{array}$ \\
\hline Northern Apennines & 172,500 & $1,540,100$ & 865 & 23.0 & -1.6 & 212 & 226 & 174 & 300 & 912 \\
\hline Central Apennines & 631,000 & $1,964,700$ & 1004 & 24.5 & -1.0 & 201 & 197 & 166 & 272 & 836 \\
\hline Southern Apennines & 297,500 & $1,925,400$ & 905 & 24.2 & 1.5 & 255 & 174 & 89 & 240 & 759 \\
\hline Total average & $1,101,000$ & $5,430,200$ & 933 & 24.0 & -0.3 & 222 & 196 & 142 & 268 & 830 \\
\hline
\end{tabular}


mainly concentrated along the central Apennines (-22.8\% and $-9.3 \%$ under A2 and B2, respectively). The highest reductions are expected in summer (Prec_JJA) by $-48.5 \%$ and $-41.5 \%$ under A2 and B2 scenarios, respectively.

\section{Random forest validation}

The calibrated RF model, applied on the validation subset, proved to be robust resulting in a CAE of $12 \%$, when using the same TSS threshold identified in the calibration process (i.e., $>0.5$ ). When RF model was applied over the entire dataset, the overall CAE resulted 19\%, reflecting in a general over-estimation of current pastures distribution $(\mathrm{CAE}=23 \%)$. In particular, according to RF simulations, areas climatically suited to pastures account for $2,344,000$ ha, a wider area with respect to the observed pastureland coverage, as reported by CLC map $(1,101,000$ ha). However, as showed in Figure 1, most of misclassifications (false positive) were predicted in a distance below 1-2 km - which in turn is the spatial resolution of the dataset - of the observed truepositive.

Table 2. Variations of climate parameters, as projected by HadCM3 with respect to the current climatology in two time slices (centred in 2050 and 2080) under $A 2$ and B2 emission scenarios. TMAX_Jul and TMIN_Jan refer to variation in ${ }^{\circ} \mathrm{C}$ of the average of the mean maximum temperature of the warmest month (July) and of the minimum temperature of the coldest month (January) with respect to the current climatology, respectively. Prec_Ann refers to the percentage of variation in annual precipitation with respect to present. Prec_DJF, Prec_MAM, Prec_JJA and Prec_SON are the differences in percentage of the average rainfall during the winter, spring, summer and autumn season along the study area, respectively.

\begin{tabular}{|c|c|c|c|c|}
\hline Delta TMIN_Jan $\left({ }^{\circ} \mathrm{C}\right)$ & 2050 A2 & 2080 A2 & 2050 B2 & 2080 B2 \\
\hline Northern Apennines & 2.3 & 3.8 & 2.1 & 2.5 \\
\hline Central Apennines & 1.7 & 3.1 & 1.7 & 2.1 \\
\hline Southern Apennines & 1.2 & 2.5 & 1.5 & 1.8 \\
\hline Average & 1.3 & 2.8 & 1.4 & 1.8 \\
\hline Delta TMAX_Jul $\left({ }^{\circ} \mathrm{C}\right)$ & 2050 A2 & 2080 A2 & 2050 B2 & 2080 B2 \\
\hline Northern Apennines & 5.2 & 9.4 & 4.6 & 6.4 \\
\hline Central Apennines & 5.6 & 8.8 & 5.1 & 6.8 \\
\hline Southern Apennines & 2.7 & 4.9 & 2.6 & 3.7 \\
\hline Average & 4.5 & 7.6 & 4.1 & 5.6 \\
\hline Delta Prec_Ann (\% mm) & $2050 \mathrm{~A} 2$ & 2080 A2 & 2050 B2 & 2080 B2 \\
\hline Northern Apennines & -3.2 & -15.0 & -2.2 & -0.9 \\
\hline Central Apennines & -6.8 & -22.8 & -6.8 & -9.3 \\
\hline Southern Apennines & -5.0 & -15.1 & -5.1 & -5.7 \\
\hline Average & -5.3 & -18.1 & -5.0 & -5.9 \\
\hline Delta Prec_DJF (\% mm) & 2050 A2 & 2080 A2 & 2050 B2 & $2080 \mathrm{~B} 2$ \\
\hline Northern Apennines & 15.4 & 20.4 & 13.8 & 35.6 \\
\hline Central Apennines & 9.3 & 10.2 & 8.3 & 32.1 \\
\hline Southern Apennines & -2.6 & 2.2 & -3.1 & 14.9 \\
\hline Average & 6.9 & 10.2 & 5.9 & 27.2 \\
\hline Delta Prec_MAM ( $\% \mathrm{~mm})$ & 2050 A2 & 2080 A2 & 2050 B2 & 2080 B2 \\
\hline Northern Apennines & 2.6 & -21.5 & -7.2 & 2.2 \\
\hline Central Apennines & 1.5 & -31.8 & -13.6 & -14.7 \\
\hline Southern Apennines & 1.6 & -25.5 & -7.6 & -14.2 \\
\hline Average & 1.9 & -27.0 & -9.9 & -10.1 \\
\hline Delta Prec_JJA (\% mm) & 2050 A2 & $2080 \mathrm{A2}$ & 2050 B2 & 2080 B2 \\
\hline Northern Apennines & -31.8 & -47.0 & -27.3 & -36.7 \\
\hline Central Apennines & -38.4 & -53.0 & -32.7 & -46.3 \\
\hline Southern Apennines & -29.6 & -44.5 & -23.8 & -39.6 \\
\hline Average & -33.7 & -48.5 & -28.3 & -41.5 \\
\hline Delta Prec_SON (\% mm) & 2050 A2 & 2080 A2 & 2050 B2 & 2080 B2 \\
\hline Northern Apennines & -4.2 & -16.8 & 4.8 & -8.5 \\
\hline Central Apennines & -5.4 & -22.0 & 3.0 & -13.1 \\
\hline Southern Apennines & -2.6 & -14.0 & 2.3 & -7.6 \\
\hline Average & -4.1 & -17.9 & 3.2 & -10.0 \\
\hline
\end{tabular}


According to mean decrease accuracy (MDA) analysis, the parameters Prec_MAM and TMAX_Jul were the most important in predicting the presence of pastures, while TMIN_Jan showed the lowest prediction potential (Figure 2).

\section{Current and future pastureland suitability distribution}

The robust and coherent calibrated RF model was applied to the predictor variables calculated for the two time slices (2050 and 2080) in order to derive pastureland suitability under A2 and B2 scenarios. On average, the range of lands suited to pastures denoted a remarkable contraction in the near and next future of both scenarios (Figure 3). Particularly, the highest reductions in pastures suitability $(-46 \%$ and $-41 \%$ under $\mathrm{A} 2$ and $\mathrm{B} 2$ scenarios, respectively), coupled with a rise in the mean altitude $(+110 \mathrm{~m})$, are projected by the middle of the century (2040-2069). In the next future (2070-2099), areas potentially suitable for pastures show a remarkable reduction $(-41 \%$ and $-33 \%$ under A2 and B2 scenarios, respectively) with respect to the baseline period, though in a lower magnitude than in 2050 time slice (Table 3 ). In the specific, in the next future the remarkable reductions in pasturelands suitability predicted under both scenarios along the northern $(-69 \%$ and $-71 \%$ under $\mathrm{A} 2$ and $\mathrm{B} 2$ scenarios, respectively) and central Apennines ( $-90 \%$ under both scenarios) are counterbalanced by relevant expansions along the southern areas of the chain $(+96 \%$ and $+105 \%$ under A2 and B2 scenarios, respectively). Pasturelands located along the Central Apennines are expected to face the highest reductions, showing a relevant decrement in suitable areas by $-83 \%$ and $78 \%$ in $\mathrm{A} 2$ and $\mathrm{B} 2$ scenarios, respectively, by the middle of the century with respect to the baseline period. Conversely, the most noteworthy shift in altitude of areas suited to pastures is predicted across the central Apennines in the near future (2050) in both scenarios (+507 m and $+422 \mathrm{~m}$ under $\mathrm{A} 2$ and $\mathrm{B} 2$ scenarios, respectively).

\section{Discussion and conclusions}

The use of pre-existent spatial dataset coupled with RF model proved to be effective to predict potentially suitable areas for pasturelands characterising the Apennines chain under current climate. In particu-

Table 3. Variations of suitability areas for pastures and altitudinal shifts with respect to baseline period (1990-2000) expressed in percentage (variation in coverage) and in absolute values (meters variation in altitude) in two time slices (centred in 2050 and 2080) under $A 2$ and $B 2$ emission scenarios, as simulated by HadCM3.

\begin{tabular}{lrrrr} 
Zone & A2 2050 & A2 2080 & B2 2050 & B2 2080 \\
\hline Variation in coverage (\%) & & & \\
Northern Apennines & -25 & -69 & -10 & -71 \\
Central Apennines & -83 & -90 & -78 & -90 \\
\hline Southern Apennines & +19 & +96 & +21 & +105 \\
Total average & -46 & -35 & -41 & -33 \\
\hline Variation in altitude & & & & \\
\hline Northern Apennines & +105 & -125 & +137 & +188 \\
Central Apennines & +507 & +90 & +422 & +203 \\
\hline Southern Apennines & +168 & +20 & +56 & +52 \\
Total average & +140 & -76 & +80 & -22 \\
\hline
\end{tabular}

lar, RF performances resulted in a good trade-off between precision and generality, considering the large scale of the study area. Similar conclusions have reached previous studies carried out on Italian natural forests (Attorre et al., 2011; Casalegno et al., 2011) and Alpine permanent grasslands (Dibari, 2012; Dibari et al., 2013), both performed on a largescale basis. Of course, the spatial resolution of this work (100 ha) includes a wide territory, comprising a high variety of different environmental and topographic characteristics as well as relevant pastoral het-

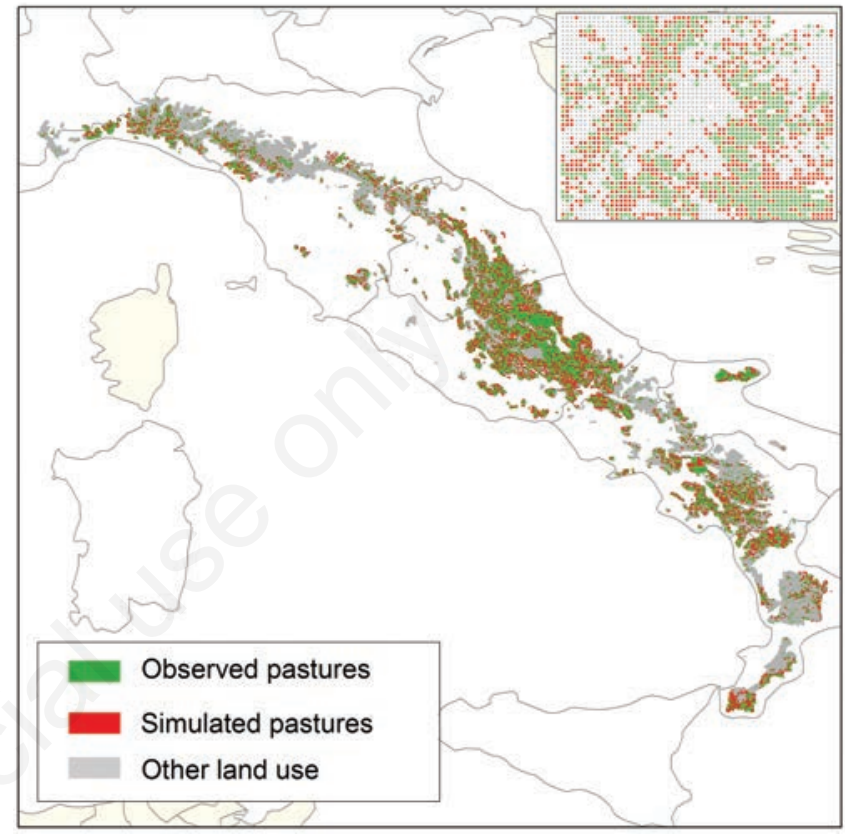

Figure 1. Observed (green dots) and simulated (red dots) pastureland distribution over the Apennines chain for the present period.

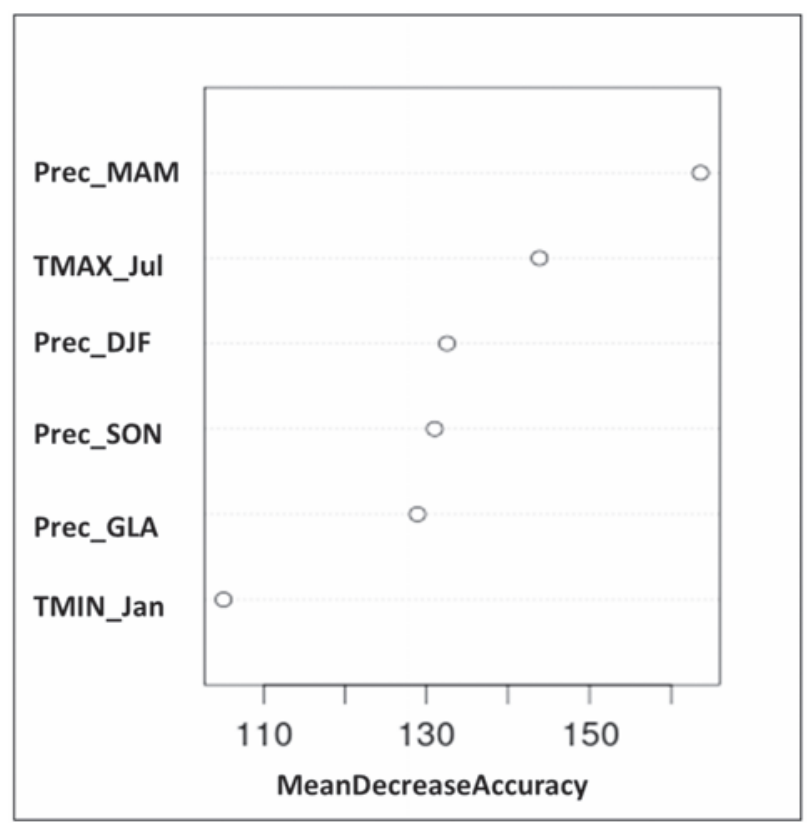

Figure 2. Variable importance based on the mean decrease accuracy deriving from random forest calibration. 
erogeneity, which may be determining in mountain ranges. However, this study aimed at comprehensively evaluating potential suitability for pastures along the entire Apennines chain, assuming climate as the main driver, without considering human influence, or any other local environmental factors (e.g., soil nutritional factors, ecological processes, microclimate, etc.), determinant at a finer scale (Riedo et al., 2011; Komac et al., 2014). Moreover, the empirical statistical method used did not consider vegetation successions and inter-actions, but rather intrinsically incorporated the long lasting influence of species competition, through fitting pasture response to the environmental predictors. In this context, Prec_MAM and TMAX_Jul resulted the most determinant predictors in the classification process (MDA analysis), even though the other climatic variables play a role in the model. Only the mean minimum temperature of the coldest month (TMIN_Jan) resulted not included among the most dominant variables. This likely means that this variable does not perform particularly well for the scale and resolution of the study (Casalegno et al., 2011). Being in this study model predictors related to climate, pastureland suitability maps resulted from the RF classification process represent areas that are best fitted to the corresponding environment, i.e., with the highest probability of presence of pastures. For this reason, the overestimation of current pastureland distribution $(\mathrm{CAE}=12 \%)$, derived from the application of RF model over the entire dataset, can be considered reasonable, since most of the misclassified predicted pastures were located within a distance of 1-2 km with respect to the observed pastoral areas, thus in areas potentially suited to pastures. Furthermore, codes extracted by the CLC map, are very heterogeneous representing a wide variety of grassland species and communities with different climate exigencies. Also this issue may have caused an overestimation of pastoral areas for the present period. Likely, a focus on category 321 (Natural grasslands) only, may have reduced the classification error, though consistent drawbacks might result in the extent of the analysis of the study. Future climate predictions, as simulated by HadCM3, presented some constraints. In particular, by the end of the century, the highest increases in TMAX_Jul are foreseen on the northern zone of the chain $\left(+9.4^{\circ} \mathrm{C}\right)$ rather than on the southern $\left(+4.9^{\circ} \mathrm{C}\right)$. Similarly, by the end of the century in $\mathrm{A} 2$ scenario the GCM predicts the highest decreases in annual precipitation along the central Apennines rather than along the southern zone. This constraint, risen also by Pearson and Dawson (2003), likely determined a non-linear response of $\mathrm{RF}$ predictions in this study. This is probably due to the coarse spatial resolution of $\mathrm{HadCM} 3$ cells ( $2.5^{\circ}$ lat. and $3.75^{\circ}$ long.), strongly influenced by the Mediterranean Sea's reliever effect especially in southern Italy. The use of climatic models with a higher spatial resolution (i.e., Regional Climate Models - RCM), tailored for analysis at regional scale, could likely overcome this issue (Sousanna et al., 2010). According to RF model simulation, a noteworthy loss of suitability areas for pasturelands resulted across the northern-central Apennines by the end of the century in both the considered emission scenarios ( $-79 \%$ and $-81 \%$ under A2 and B2 scenario, respectively). This figure is particularly alarming considering that the northern-central areas of the chain currently host $72 \%$ out of total mountain pastures of the Apennines. This general trend, as well as an overall shift of pastures suitable areas to higher altitudes, is confirmed by similar studies which examined future climate impacts on grasslands at European (Engler et al., 2011; Gottfried et al., 2012; Pauli et al., 2012), at Alpine (Cannone et al., 2007; Vittoz et al., 2009; Dibari, 2012; Dibari et al., 2013) and at regional (Stanisci, 2005a, 2005b; Gavazov et al., 2014) level.

As pointed out by Benvenuti (2009) and Bütof et al. (2012), reductions
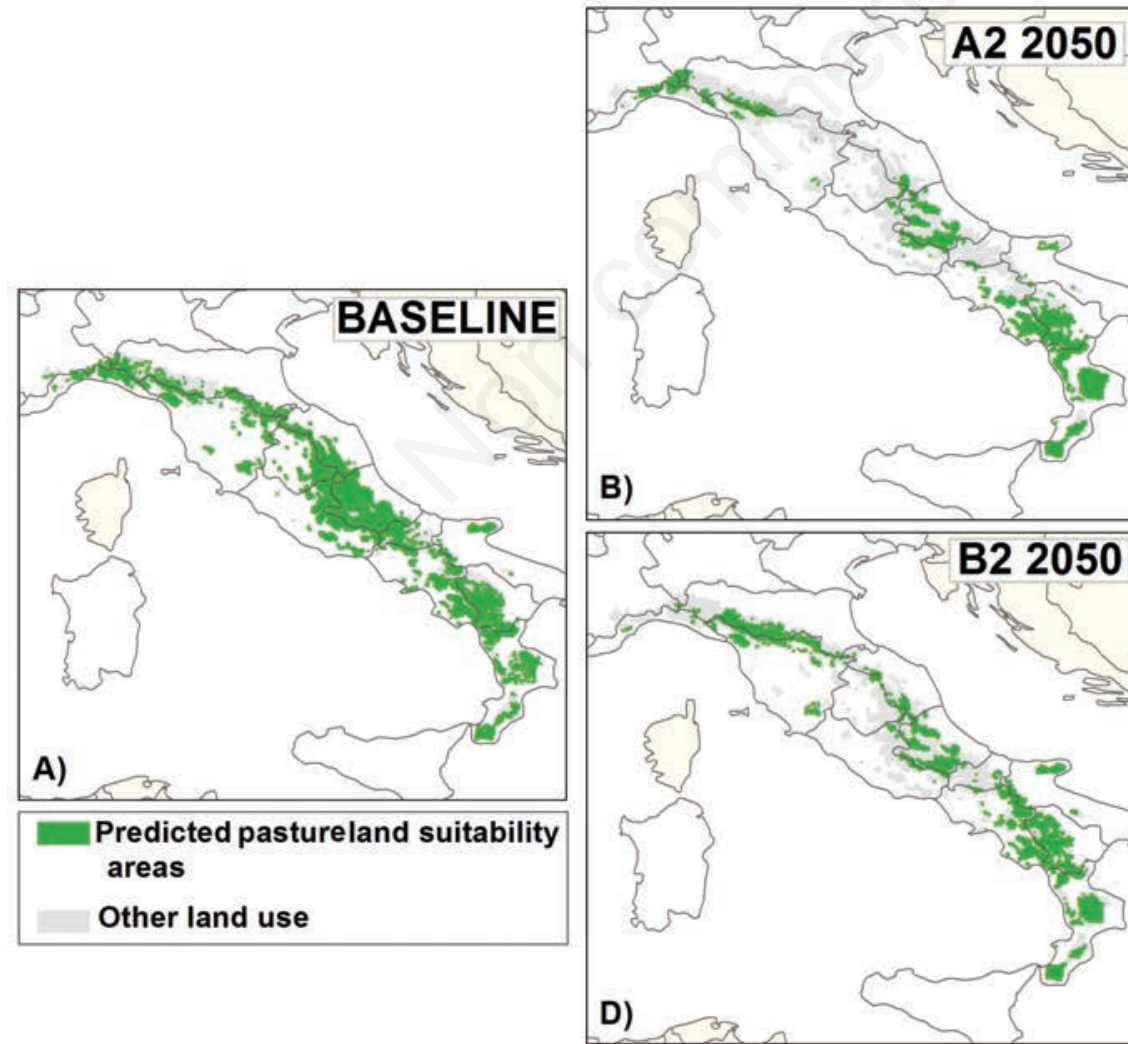

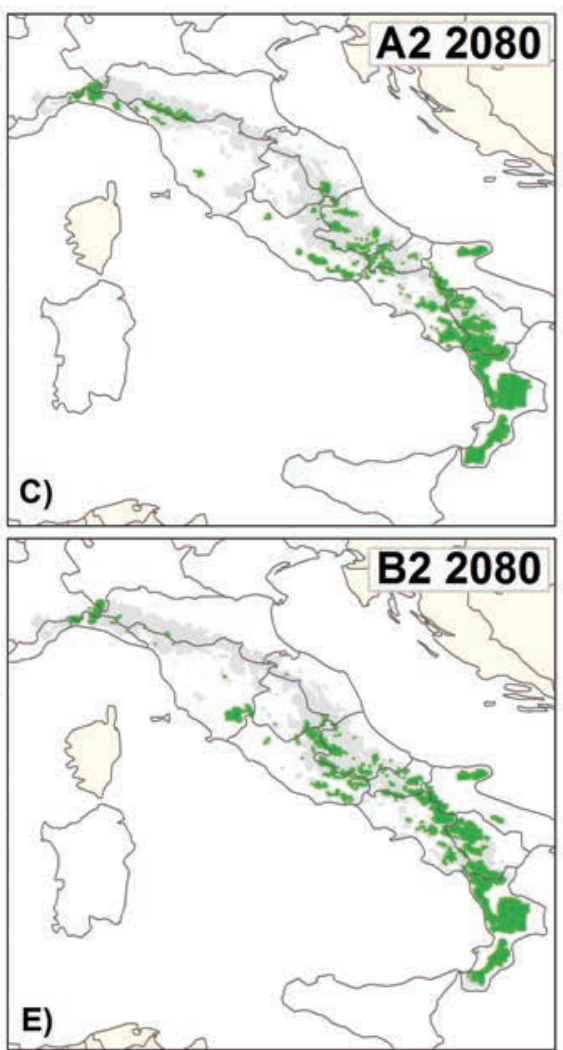

Figure 3. Maps of predicted pastureland suitability areas for the baseline (1905-2000) (A) and for two future time slices centred in 2050 $(\mathrm{B}, \mathrm{D})$ and $2080(\mathrm{C}, \mathrm{E})$ in A2 and B2 scenarios as simulated by HadCM3 global circulation model. 
in precipitation due to climate change play a determinant role on reductions in grasslands distribution. This is evident along the central Apennines, where by the end of the century in $\mathrm{A} 2$ scenario considerable decreases in pastures suitability $(-90 \%)$ is coupled with decrements in spring precipitation (Prec_MAM=-32\%), and with relevant increases in TMAX_Jul $\left(+8.8^{\circ} \mathrm{C}\right)$, the most important variables according to MDA analysis. In contrast, the increments of pastures suitability resulted along the southern Apennines in the next future (2080 time slice) under A2 and B2 scenarios are combined with decreases in Prec_MAM (-25\% and $14.2 \%$ under A2 and B2 scenarios, respectively) and a slighter increment in TMAX_Jul $\left(+4.9^{\circ} \mathrm{C}\right.$ and $+3.7^{\circ} \mathrm{C}$, under $\mathrm{A} 2$ and $\mathrm{B} 2$ scenarios $)$ with respect to the central area. This may be probably due to species composition characterising the southern Apennines pastures. In fact xeric and thermophiles grassland species, will likely benefit from warmer and drier future conditions as predicted in the southern zone of the chain by the HadCM3. This hypothesis is confirmed by Dibari (2012) who, assessing climate change impacts on seven pasture macro-types along the Alpine chain, observed a remarkable expansion of pastures dominated by xeric species and by Nardus stricta at the end of the century. Moreover, it is likely that the remarkable reductions in pasturelands distribution at a large scale will be associated to variation in vegetation composition (Nautiyal et al., 2004) or to richness species loss at ecosystem scale, as observed in experimental plots (Gavazov et al., 2014). Finally, the predicted changes in climate coupled with an increasing abandonment of the traditional grazing practices occurred in the last decades (Cavallero et al., 2002) will likely lead to long lasting impacts in terms of grassland biodiversity loss and, as consequence, a decline in environmental services provided by the Apennine pastoral ecosystems.

In conclusion, by this study RF machine-learning model proved to be reliable and robust to reproduce current pastureland suitability areas. Moreover, the validated RF model was used to assess climate change impacts on pasture distribution along the Apennine chain. Anyway, the use of models for predicting impacts of climate change on natural resources may be biased by uncertainties (Tubiello et al., 2007) due to the high simplification assumed by models that can reduce the level of confidence, especially when operating at regional level (Sousanna et al., 2010). The effects of pasture management and their interactions with climate would need a separate ad hoc analysis, which goes beyond the objectives of the present study. Future developments of this study may consider the use of climate models with RCM, commonly used for climate predictions at regional level, to face uncertain and constraints previously pointed out (Sousanna et al., 2010). Moreover, possible enhancement of the present research may consider the inclusion of other predictors (e.g., soil parameters) and the analysis of pasture composition and its evolution in the future, also taking into account new climate change scenarios produced by the latest IPCC report (IPCC, 2014).

\section{References}

Allouche 0, Tsoar A, Kadmon R, 2006. Assessing the accuracy of species distribution models: prevalence, kappa and the true skill statistic (TSS). J. Appl. Ecol. 43:1223-32.

Araújo MB, Luoto M, 2007. The importance of biotic interactions for modelling species distributions under climate change. Global Ecol. Biogeogr. 16:743-53.

Attorre F, Alfò M, De Sanctis M, Francesconi F, Valenti R, Vitale M, Bruno F, 2011. Evaluating the effects of climate change on tree species abundance and distribution in the Italian peninsula. Appl. Veg. Sci. 14:242-55.

Austin M, 2007. Species distribution models and ecological theory: A critical assessment and some possible new approaches. Ecol.
Model 200:1-19

Benvenuti S, 2009. Potenziale impatto dei cambiamenti climatici nell'evoluzione floristica di fitocenosi spontanee in agroecosistemi mediterranei [Potential impact of climate change on the evolution of spontaneous plant communities in Mediterranean agroecosystems]. Ital. J. Agron. / Riv. Agron. 4(Suppl 1):45-67.

Biondi E, Blasi C, Burrascano S, Casavecchia S, Copiz R, Del Vico E, Galdenzi D, Gigante D, Lasen C, Spampinato G, Venanzoni R, Zivkovic L, 2009. Manuale Italiano di interpretazione degli habitat della Direttiva 92/43/CEE. Società Botanica Italiana. Ministero dell'Ambiente e della tutela del territorio e del mare, D.P.N. Available from: http:/vnr.unipg.it/habitat/

Bravo DN, Araújo MB, Lasanta T, Moreno JIL, 2008. Climate change in Mediterranean mountains during the 21st century. J. Hum. Environ. $37: 280-5$.

Breiman L, 2001. Random forests. Mach. Learn. 45:5-32.

Bütof A, von Riedmatten LR, Dormann CF, Scherer-Lorenzen M, Welk E, Bruelheide $\mathrm{H}, 2012$. The responses of grassland plants to experimentally simulated climate change depend on land use and region. Glob. Chang. Biol. 18:127-37.

Cannone N, Sgorbati S, Guglielmin M, 2007. Unexpected impacts of climate change on alpine vegetation. Front. Ecol. Eviron. 5:360-4.

Carlier L, Rotar I, Vlahova M, Vidican R, 2009. Importance and functions of grasslands. Not. Bot. Hort. Agrobot. Cluj 37:25-30.

Casalegno S, Amatulli G, Bastrup-Birk A, Durrant TH, Pekkarinen A, 2011. Modelling and mapping the suitability of European forest formations at 1-km resolution. Eur. J. For. Res. 130:971-81.

Cavallero A, Rivoira G, Talamucci P, 2002. Pascoli. In: R. Baldoni and L. Giardini (Eds.), Coltivazioni erbacee. Foraggere e tappeti erbosi. Patron Editore, Bologna, Italy, pp 239-294.

Cornelius C, Leingärtner A, Hoiss B, Krauss J, Ingolf SD, Menzel A, 2012. Phenological response of grassland species to manipulative snowmelt and drought along an altitudinal gradient. J. Exp. Bot. 64:241-51.

Dibari C, 2012. Caratterizzazione territoriale delle risorse pastorali delle Alpi Italiane per lo studio degli impatti dei cambiamenti climatici. Ph.D. Thesis, Università di Firenze, Firenze, Italy.

Dibari C, Argenti G, Moriondo M, Staglianò N, Targetti S, Bindi M, 2013. Climate change impacts on distribution and composition of the Alpine Natural Pasturelands. pp 578-586 in Proc. 1st Annual Conference Climate change and its implications on ecosystem and society. Società Italiana per le Scienze del Clima, Lecce, Italy.

Dibari C, Bindi M, Moriondo M, Staglianò N, Targetti S, Argenti G, 2015. Spatial data integration for the environmental characterization of pasture macro-types in the Italian Alps. Grass and Forage Sci. [Epub ahead of print]

Engler R, Randin CF, Thuiller W, Dullinger S, Zimmermann NE, Araújo MB, Pearman PB, Le Lay G, Piedallu C, Albert CH, Choler P, Coldea G, De Lamo X, Dirnböck T, Gégout JC, Gómez-García D, Grytnes JA, Heegaard E, Høistad F, Nogués-Bravo D, Normand S, Pu ca M, Sebastià MT, Stanisci A, Theurillat JP, Trivedi MR, Vittoz P, Guisan A, 2011. 21st century climate change threatens mountain flora unequally across Europe. Glob. Change Biol. 17:2330-41.

Evans JS, Cushman SA, 2009. Gradient modelling of conifer species using random forests. Lands. Ecol. 24:673-83.

Evans JS, Murphy MA, Holden ZA, Drew CA, Wiersma YF, Huettmann F, 2011. Modeling species distribution and change using random forest. In: C.A. Drew, Y.F. Wiersma, F. Huettmann (Eds.), Predictive species and habitat modeling in landscape ecology. Springer Science+ Business Media, Berlin, Germany, pp 139-159.

Gaál M, Moriondo M, Bindi M, 2012. Modelling the impact of climate change on the Hungarian wine regions using random forest. Appl. Ecol. Environ. Res. 10:121-40. 
Gasith A, Vincent HR, 1999. Streams in Mediterranean climate regions: abiotic influences and biotic responses to predictable seasonal events. Annu. Rev. Ecol. Syst. 30:51-81.

Gavazov K, Spiegelberger T, Buttler A, 2014. Transplantation of subalpine wood pasture turfs along a natural climatic gradient reveals lower resistance of unwooded pastures to climate change compared to wooded ones. Oecol. 174:1425-35.

Giorgi F, Lionello P, 2008. Climate change projections for the Mediterranean region. Global Planet Change 63:90-104.

Gottfried M, Pauli H, Futschik A, Akhalkatsi M, Baran ok P, Alonso JLB, Coldea G, Jan D, Erschbamer B, Calzado MRF, Kazakis G, Kraj i J, Larsson P, Mallaun M, Michelsen 0, Moiseev D, Moiseev P, Molau U, Merzouki A, Nagy L, Nakhutsrishvili G, Pedersen B, Pelino G, Puscas M, Rossi G, Stanisci A, Theurillat JP, Tomaselli M, 2012. Continentwide response of mountain vegetation to climate change. Nature Climate Change 2:111-5.

Gottfried M, Pauli H, Reiter K, Grabherr G, 1999. A fine scaled predictive model for changes in species distribution patterns of high mountain plants induced by climate warming. Div. Distrib. 5:241-51.

Guisan A, Theurillat JP, 2000. Equilibrium modeling of alpine plant distribution: how far can we go?. Phytocoenologia 30:353-84.

Heimann D, Sept V, 2000. Climate change estimates of summer temperature and precipitation in the Alpine region. Theor. Appl. Climatol. 66:1-12.

Hertig E, Seubert S, Jacobeit J, 2010. Temperature extremes in the Mediterranean area: trends in the past and assessments for the future. Nat. Hazard Earth Sys. 10:2039-50.

Hijmans RJ, Cameron SE, Parra JL, Jones PG, Jarvis A, 2005. Very high resolution interpolated climate surfaces for global land areas. Int $\mathbf{J}$ Climatol 25:1965-78.

IPCC, 2014. Climate change: impacts, adaptation, and vulnerability. Contribution of Working Group II to the Fifth Assessment Report of the Intergovernmental Panel on Climate Change. Cambridge University Press, Cambridge, United Kingdom and New York, NY, USA, 1132 pp.

Knapp AK, Beier C, Briske DD, Classen AT, Luo Y, Reichstein M, Smith MD, Smith SD, Bell JB, Fau PA, Heisler JL, Leavitt SW, Sherry R, Smith B, Weng E, 2008. Consequences of more extreme precipitation regimes for terrestrial ecosystems. BioSci. 58:811-21.

Komac B, Domènech M, Fanlo R, 2014. Effects of grazing on plant species diversity and pasture quality in subalpine grasslands in the eastern Pyrenees (Andorra): implications for conservation. J. Nat. Cons. 22:247-55.

Kudernatsch T, Fischer A, Bernhardt-Romermann M, Abs C, 2008. Shortterm effects of temperature enhancement on growth and reproduction of alpine grassland species. Basic Appl. Ecol. 9:263-74.

Latimer AM, Wu S, Gelfand AE, Silander JJA, 2006. Building statistical models to analyze species distributions. Ecol. Appl. 16:33-50.

Lionello P, Abrantes F, Gacic M, Planton S, Trigo R, Ulbrich U, 2014. The climate of the Mediterranean region: research progress and climate change impacts. Reg. Environ. Change 14:1679-84.

Lionello P, Malanotte-Rizzoli P, Boscolo R, Alpert P, Artale V, Li L, Luterbacher J, May W, Trigo R, Tsimplis M, Ulbrich U, Xoplaki E, 2006. The Mediterranean climate: an overview of the main characteristics and issues. In: P. Lionello, P. Malanotte-Rizzoli and R. Boscolo (Eds.), Mediterranean climate variability. Elsevier, Amsterdam, The Netherlands, pp 1-26.

Moriondo M, Jones GV, Bois B, Dibari C, Ferrise R, Trombi G, Bindi M, 2013a. Projected shifts of wine regions in response to climate change. Clim. Change 119:825-39.

Moriondo M, Trombi G, Ferrise R, Brandani G, Dibari C, Ammann CM,
Mariotti Lippi M, Bindi M, 2013b. Olive trees as bio indicators of climate evolution in the Mediterranean Basin. Global Ecol. Biogeogr. 22:818-33.

Moriondo M, Stefanini FM, Bindi M, 2008. Reproduction of olive tree habitat suitability for global change impact assessment. Ecol. Model. 218:95-109.

Nautiyal MC, Nautiyal BP, Prakash V, 2004. Effect of grazing and climatic changes on alpine vegetation of Tungnath, Garhwal Himalaya, India. Environmental 24:125-34.

Pasho E, Papanastasis VP, Pelz D, Lako T, 2011. Inventory and evaluation of grasslands in Albania. Grass Forage Sci. 66:123-37.

Pauli H, Gottfried M, Dullinger S, Abdaladze 0, Akhalkatsi M, Alonso JLB, Coldea G, Dick J, Erschbmaer B, Calzado RF, Ghosn D, Holten JI, Kanka R, Kazakis G, Kollàar J, Larson P, Moiseev P, Moiseev D, Molau U, Mesa JM, Nagy L, Pelino G, Pu ca M, Rossi G, Stanisci A, Syberhuset A0, Theurillat JP, Tomaselli M, Unterluggauer P, Villar L, Vittoz P, Grabherr G, 2012. Recent plant diversity changes on Europe's mountain summits. Science 336:353-5.

Pearson RG, Dawson TP, 2003. Predicting the impacts of climate change on the distribution of species: are bioclimate envelope models useful? Glob Ecol. Biogeogr. 12:361-71.

Pope VD, Gallani ML, Rowntree PR, Stratton RA, 2000. The impact of new physical parameterizations in the Hadley Centre climate model HadAM3. Clim Dynam 16:123-46.

Prasad A, Iverson L, Liaw A, 2006. Newer classification and regression tree techniques: bagging and random forests for ecological prediction. Ecosystems 9:181-99.

Prentice IC, Cramer W, Harrison SP, Leemans R, Monserud RA, Solomon AM, 1992. Special paper: a global biome model based on plant physiology and dominance, soil properties and climate. J. Biogeogr. 19:117-34.

Riedo M, Gyalistras D, Fuhrer J, 2011. Pasture responses to elevated temperature and doubled $\mathrm{CO} 2$ concentration: assessing the spatial pattern across an alpine landscape. Clim. Res. 17:19-31.

Soussana JF, Graux AI, Tubiello FN, 2010. Improving the use of modelling for projections of climate change impacts on crops and pastures. J. Exp. Bot. 61:2217-28.

Stanisci A, Pelino G, Blasi C, 2005a. Vascular plant diversity and climate change in the alpine belt of the central Apennines (Italy). Biodivers. Conserv. 14:1301-18.

Stanisci A, Pelino G, Guisan A, 2005b. Cambiamenti climatici ed effetti sulla flora di alta quota nel Parco Nazionale della Majella. In: M. Di Cecco and T. Andrisiano (Eds.), Proc. "La Biodiversità vegetale nelle aree protette in Abruzzo studi ed esperienze a confronto", 29 ottobre 2005, Lama dei Peligni (CH), pp 192-210.

Targetti S, Staglianò N, Messeri A, Argenti G, 2010. A state-and-transition approach to alpine grasslands under abandonment. iForest 3:44-51.

Thuiller W, Albert C, Araùjo MB, Berry PM, Cabeza M, Guisan A, Hicker T, Midgley GF, Paterson J, Schurr FM, Skyes MT, Zimmermann NE, 2008. Predicting global change impacts on plant species' distributions: future challenges. Perspect. Plant. Ecol. 9:137-52.

Todd AW, Campbell BD, Kemp PD, Hunt CL, 2000. Sensitivity of three grassland communities to simulated extreme temperature and rainfall events. Glob. Change Biol. 6:671-84.

Tubiello FN, Soussana JF, Howden MS, 2007. Crop and pasture response to climate change. Proc. Natl. Acad. Sci. U. S. A. 104:19686-90.

Vittoz P, Randin C, Dutoit A, Bonnet F, Hegg 0, 2009. Low impact of climate change on subalpine grasslands in the Swiss Northern Alps. Glob. Chang. Biol. 15:209-20. 